\title{
Laparoscopic intracorporal colorectal sutured anastomosis using the Radius Surgical System in a phantom model
}

\author{
J. R. Torres Bermudez $\cdot$ G. Buess $\cdot$ M. Waseda $\cdot$ \\ I. Gacek - F. Becerra Garcia - G. A. Manukyan • \\ N. Inaki
}

Published online: 3 April 2009

(C) Springer Science+Business Media, LLC 2009

\section{Erratum to: Surg Endosc}

DOI 10.1007/s00464-008-9992-y

The correct spelling of the last author's name is N. Inaki.

The online version of the original article can be found under doi:10.1007/s00464-008-9992-y.

J. R. Torres Bermudez $(\bowtie) \cdot$ G. Buess $\cdot$ M. Waseda .

I. Gacek · N. Inaki

Section for Minimaly Invasive Surgery, Department of General,

Visceral and Transplantation Surgery, Tuebingen University,

Tuebingen, Germany

e-mail: ricardo970sigma@yahoo.com

F. Becerra Garcia

Servicio de Cirugía General y Endoscópica,

Hospital "Dr. Manuel Gea Gonzalez", Mexico, DF, Mexico

G. A. Manukyan

Department of Endoscopic Surgery, National Institute of Health,

Yerevan, Armenia 